\title{
Archaeological Testing and Preliminary Archival Investigations of the Ruben Hancock Site, 41TV875 Travis County, Texas
}

John W. Clark Jr.

Follow this and additional works at: https://scholarworks.sfasu.edu/ita

Part of the American Material Culture Commons, Archaeological Anthropology Commons, Environmental Studies Commons, Other American Studies Commons, Other Arts and Humanities Commons, Other History of Art, Architecture, and Archaeology Commons, and the United States History Commons

Tell us how this article helped you.

This Article is brought to you for free and open access by the Center for Regional Heritage Research at SFA ScholarWorks. It has been accepted for inclusion in Index of Texas Archaeology: Open Access Gray Literature from the Lone Star State by an authorized editor of SFA ScholarWorks. For more information, please contact cdsscholarworks@sfasu.edu. 


\section{Archaeological Testing and Preliminary Archival Investigations of the Ruben Hancock Site, 41TV875 Travis County, Texas}

\section{Licensing Statement}

This is a work produced for the Texas Department of Transportation (TxDOT) by the report producer. TxDOT and the report producer jointly own all rights, title, and interest in and to all intellectual property developed under TXDOT's contract with the report producer. The report may be cited and brief passages from this publication may be reproduced without permission provided that credit is given to both TXDOT and the report producer. Permission to reprint an entire chapter, section, figures or tables must be obtained in advance from either the Supervisor of the Archeological Studies Branch, Environmental Affairs Division, Texas Department of Transportation, 125 East 11th Street, Austin, Texas, 78701 or from the report producer. 
ARCHAEOLOGICAL TESTING AND PRELIMINARY ARCHIVAL INVESTIGATIONS OF THE RUBEN HANCOCK SITE, 41TV875

TRAVIS COUNTY, TEXAS

BY

John w. Clark, Jr.

Texas

State Department of Highways and Public Transportation

Highway Design Division

Austin, Texas

March 1985 


\section{INIRODUCTION}

The Ruben Hancock Site (41TV875) is located at a position on the centerline of the extension of Parmer Lane from FM 1325 (Burnet Road) to FM 620. The site was found during a survey of the right-of-way conducted by the author on the 9th of August, 1984. Other sites were found during the survey but were too ephemeral or too disturbed to warrant further investigation. It was judged at the time of the survey that the Ruben Hancock Site, because of its undisturbed condition and the presence of metal and glass artifacts, warranted further investigation. It was suggested that the testing consist of a metal detector survey.

A grid was laid out promptly and accurately on the site by the survey crew of the State Department of Highways and Public Transportation (SDHPT) District 14 headquarters. Harry Johnson of the Right-of-way Division of District 14 secured permission from the property owners (Burnet Road Land Joint Venture, through Mr. Scott Ripley) for the metal detector survey. Edward Sutherland of District 14 coordinated the District 14 activities. At the Highway Design Environmental and Community Factors Section, James W. Barr and Frank A. Weir coordinated with the District. Tom Gorman aided in testing the metal detectors. Milton Bell, Jerry Henderson, Clyde Bullion, Ann Irwin, and Marilyn Rotter of the SDHPT Archaeology Section provided administrative, production, research, and secretarial support. 


\section{SITE DESCRIPTION AND ENVIRONMENT}

The site is situated on the left bank of Walnut Creek near its head. It is located at the foot of a low hilladjacent to the creek (Fig. 1). Evidence of cultural activities at the time of site occupation and subsequently serve to define the site boundaries. The site is bounded on the north by an abandoned east-west road which crosses the creek. The east boundary consists of a shallow ditch or trench for a buried sewer line cut into limestone bedrock. The south boundary consists of a barbed wire fence, and the west boundary is in part a stone yard fence and abandoned wood or barbed wire fence line indicated by a linear growth of hackberry trees. The highest point of the site is the northeast corner; the site slopes to the southwest. The west boundary runs parallel to the creek.

Soils at the site are alluvial-colluvial. The deposit increases in depth from nonexistent on the east side of the site where cretaceous limestone bedrock is exposed to approximately 2 to $3 \mathrm{ft}$. near the creek. The deposit consists of sandy loam and light clay originating from overbank deposition from the creek and slope-wash off the adjacent hill. The deposits contain small (2 to $3 \mathrm{~mm}$ in diameter) limestone pebbles.

Vegetation on the site consists of large and small live oaks, junipers, hackberries, smaller shrubs, and a variety of short grasses and forbs. Hackberries tend to form alignments along former fence lines. The area east of the site was a former plowed field and hence is covered in a variety of short and tall grasses and forbs. Southeast of the site is a baseball complex serving the Waters Park area. Adjacent areas to the south, west, and north are wooded.

Cultural features visible on the surface of the site include a stone-lined hand-dug well at the eastern margin of the site. Approximately $20 \mathrm{ft}$. west is a galvanized tube of a drilled well. Still farther west is an old fence dividing the site in half. Adjacent to the drilled well on the east side of the fence is a small pen formed by barbed wire and cedar (juniper) post fencing. One post in the fence contains many cut nails. 
This Page Redacted Per THC Policy 
At the northwest comer of the site is a low, dry-laid stone wall, probably the lower segment of a post and barbed wire fence, running east-west about $40 \mathrm{ft}$. and north-south about $80 \mathrm{ft}$. Along the north margin of the site is a clear swale representing an abandoned road (Fig. 2).

Artifactual evidence of occupation also is found at the site. This evidence consists of numerous tin cans and pieces of sheet iron adjacent to the hand-dug well, a concentration of barbed wire and barrel hoops at one point on the barbed wire fence, and thinly scattered pieces of wire and sheet iron in other areas of the site. One glass sherd and one plain white pearlware sherd were also observed on the surface. The only diagnostic artifacts observed were the cut nails in the fence post suggesting a pre-1890 construction., 


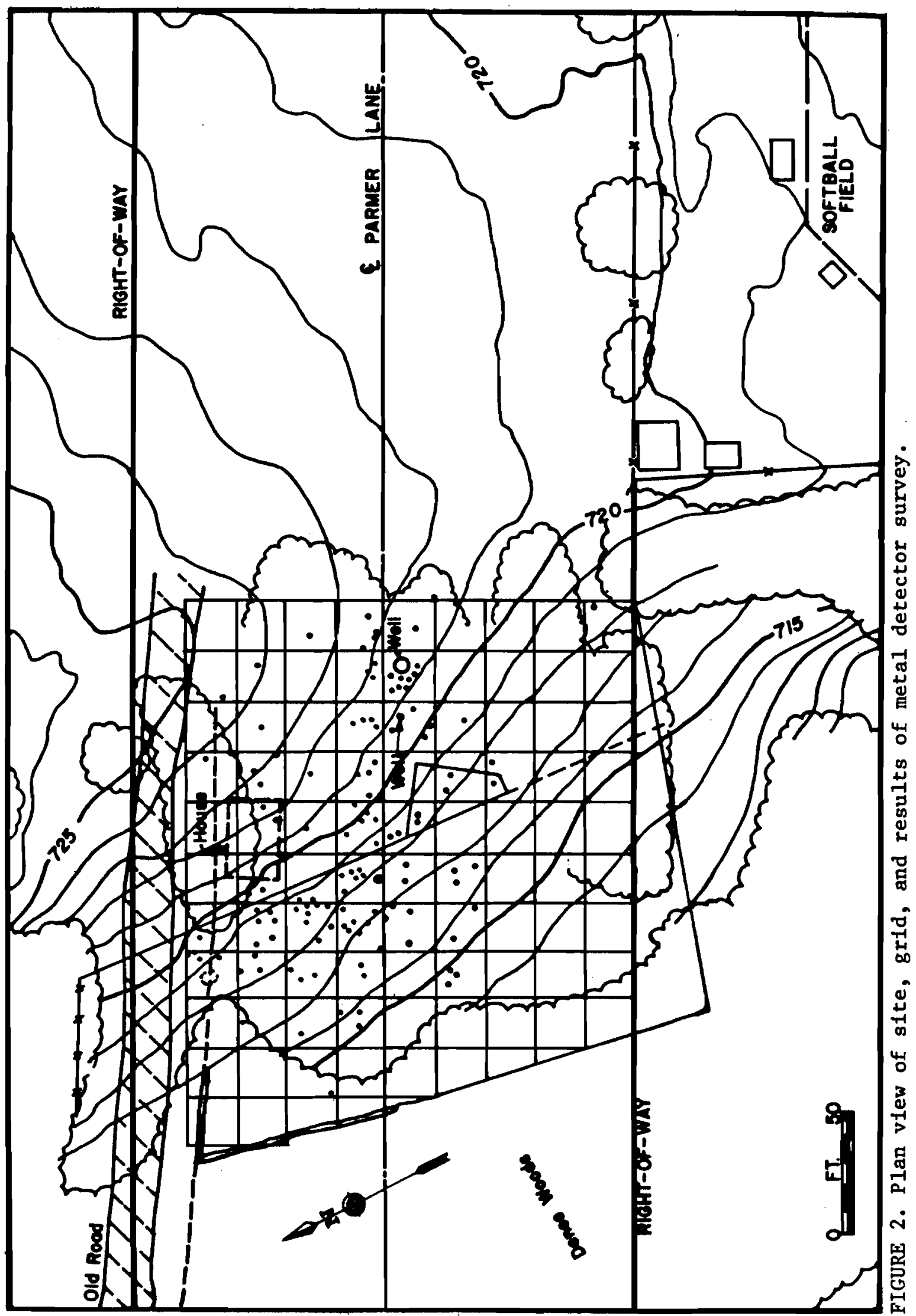




\section{PREVIOUS RESEARCH AND RESEARCH DESIGN}

Through archival investigation it was determined that this site was occupied by a Negro family from approximately 1870 to about 1920 . The his torical archaeology of ethnic groups per se is just beginning. A variety of excavations has been performed at slave cabins and pre-Civil War freeBlack sites in the northeast. This site pertains to the post-Civil War period which is poorly known through the archaeological record. Numerous Anglo sites of the period have been excavated, some in the near vicinity of this site. They provide a source of data for comparison.

The purposes of a test at an archaeological site focus on the questions of whether there 'are undisturbed deposits, buried features, and artifacts which would provide sufficient data to determine if the site is eligible for inclusion within the National Register of Historic Places. To be eligible under purely archaeological criteria, the site must have the potential to yield important archaeological information. To determine eligibility, two research endeavors were pursued. The first was the collection of archival data tracing ownership of the land and some information on the occupants of the site. The second was to locate possible artifact (metallic) concentrations in order to determine possible structures and to better define the site limits.

Since the dates of occupation were known through archival records and early aerial photos, since the presence of several cultural features was visible on the surface, and since the site is undisturbed, many of the reasons for testing were already taken care of. That really left only the question of where concentrations of artifacts might be.

In order to locate concentrations of buried artifacts, a grid of $20 \mathrm{ft}$. squares was laid on the site using the centerline as a baseline. The grid was limited to the obvious defined boundaries of the site. The grid was drawn on a topographic map of the site. Following this procedure, a metal detector was run over each square and hits plotted on the map. Surface-exposed artifacts were also plotted. 
Although the site appears to be bounded as previously described, the metal detector indicates a much smaller area of intensive occupation, an area 140 by $100 \mathrm{ft}$. (Fig. 2). The metal detector was unable to detect individual nails and strands of barbed wire. No high concentration of hits was detected in an area of the site thought to be, from surficial alignments of stone, the locality of the house. The metal detector did indicate, however, the presence of concentrations of metallic objects which was the purpose of the test. 


\section{RESULTS OF ARCHIVAL RESEARCH}

The land on which this site is situated was originally one labor of land granted to Thomas M. Fowler by the Republic of Texas in 1837 (Travis County General Land Office, File 523). Fowler assigned the land to Wilson Biggs in 1838 who in turn transferred it to John P. Harcourt, an attorney, possibly in settlement of debts (Travis County General Land Office, File 523). Harcourt retained title to the land on which one F. W. Chandler was a squatter. Harcourt obtained final clear title in 1875 (Travis County Deed Records, Vol. 31:560-561).

For some time the land title was unclear, evidently muddied by the Chandler claim. In any event, the land was owned prior to 1904 by Ruben Hancock and his heirs (Travis County Deed Records, Vol. 198:309). Affidavits by Mrs. Susie Dickerson, one of Hancock's heirs (Travis County Deed Records, Vol. 706:63-64, Vol. 700:486-488), and by Jay W. Barnes and wife Helen (Travis County Deed Records, Vol. 1489:179-183) indicate that Hancock occupied the land in 1881. Mrs. Dickerson sold the property to Earl and Flossie Gregory in 1942 (Travis County Deed Records, Vol. 700:486-488). The Gregorys later sold an easement to W. J. Simpson (Travis County Deed Records, Vol. 1435:362-363) and one to the county (Travis County Deed Records, Vol. 744:232-233). In 1954 the land was sold to J. W. Yett (Travis County Deed Records, Vol. 1489:173-178). The land eventually was purchased by the Burnet Road Land Joint Venture of Houston. 


\section{CONOUUSIONS}

Both archival research and testing through the use of a metal detector indicate that this undisturbed archaeological site contains important data of scientific interest. Testing indicates that there are cultural features in the site as well as buried artifacts. The site is associated with a Negro farmer, Ruben Hancock, and his descendants (his son, L. G. Hancock died at Waters Park in 1976). Because of the potential of the site to elucidate questions of a scientific nature, it is the opinion of the author that the site meets the criteria for nomination to the National Register of Historic Places. 